\title{
Classroom Attentiveness of Children from Home with Inter Parental Violence in Chamwino District, Tanzania
}

\author{
Simion Kaminyoge Ambakisye, PhD* \\ ORCID: 0000-0001-8409-1250 \\ Department of Psychology and Education \\ University of Iringa, Tanzania \\ *Corresponding Mail: $\underline{\text { mpokisimion@gmail.com }}$
}

\begin{abstract}
Copyright resides with the author(s) in terms of the Creative Commons Attribution CC BY-NC 4.0. The users may copy, distribute, transmit and adapt the work, but must recognize the author(s) and the East African Journal of Education and Social Sciences
\end{abstract}

\begin{abstract}
This study investigated on classroom attentiveness of children from home with inter parental violence in Chamwino, Dodoma, Tanzania. The study employed the cross-sectional survey design whereby 312 out of 652 children from five secondary schools were randomly selected to participate by filling the questionnaire. Chi square test was employed to determine the relationship between violence against mothers and children's attentiveness at the 0.05 level of significance. The results indicated a significant relationship between parental conflicts and lack of pupils' adequate concentration in learning. The findings further showed that female children whose mothers are accustomed to violence are more inattentive than male children during the teaching and learning processes. The study recommends that effective intervention strategies such as developing training through psycho education within families, schools and the community be in place.
\end{abstract}

Keywords: Domestic violence, parental violence, attentiveness, gender based violence, physical violence

How to cite: Ambakisye, S. K. (2021). Classroom Attentiveness of Children from Home with Inter Parental Violence in Chamwino District, Tanzania. East African Journal of Education and Social Sciences 2(4), 66-74. Doi: https://doi.org/10.46606/eajess2021v02i04.0129

\section{Introduction}

Children who witness fathers assaulting mothers suffer the most profound psychological distress such as depression and anxiety (Gluck, 2012; Emery, 2013) Children's experience with parental violence has been linked to variety of negative outcomes such as emotional problems (Magwa, 2013; Spilsbury, 2008; Edleson, 1999). The parental violence witnessed by the children leads to significant internalized behavior of psychological problems such as depression, anxiety, low selfesteem and social withdrawal (Moylan, Herrenkohl, Sousa, Tajma, Herrenkohl \& Russo, 2011; Zerk, Mertin \& Proeve, 2009). Intimate partner violence has consequences on the feelings of fear and anxiety on children who are exposed to it. Intimate partner violence further makes the home a place of fear rather than a place of security and comfort (UNICEF, 2006; Emery, 2013). Children fear that they might be injured during the fights between their parents, be abandoned or be blamed for the violence. Children exposed to parental violence have also conflicting feelings of distrust, anxiety, and affection as they find it difficult to understand why parents do not love each other anymore (Magwa, 2013; Spilsbury,2008). This suggests that violence between parents increases children's worry about their security and about the parents' endless conflicts.

A study from Australia by Richards (2011) indicated that children exposed to parental violence suffered psychological problems of anxiety, conflict with peers, school difficulties, low self-esteem, loneliness, aggressiveness and antisocial behavior. 
A study by Sanchez, Levison and Assaad's (2013) examined the effects of intimate partner violence against mothers on educational outcomes of children aged 6-14 years in Colombia and reported that mother's exposure to intimate partner violence led to children's school difficulties such as reluctance to learn. Jayasinghe, Jawardena and Perera (2009) in Sri Lanka revealed that children who watched, heard or observed mother injuries by the husband had poor attention in class and school attendance.

In Nigeria, a study by Abayomi (2013) on the implications of domestic violence on children's development found that children who witnessed parental violence became aggressive, troublesome at home and at school, and they isolated themselves from others. The study further showed that the children underwent more psychological problems of confusion, anxiety, and developed low self-esteem that led them into difficulties of trusting others. Jaluo's (2011) study in Kenya observed that when a mother was physically and psychologically abused by her husband, children were also affected for being confused, stressed, fearful, suffered depression and excessive absence from school. It was also revealed that the children exhibited emotional problems for crying excessively, showing shyness, had difficulty in making friends and feared adults.

A study from Tanzania by Baumgartner, Kaaya, Karungula, Kaale, Headley and Tolley (2015) showed that husbands' violence against wives or partners was common with $22-29 \%$ of women surveyed reporting being physically assaulted by their husbands or partners. The National Bureau of Statistics (2011) reported that slapping was among the most common of the husbands' acts of physical violence against their wives. Particularly the report revealed that (36\%) of married women experienced slapping, followed by being punched (18\%), and being pushed, or had something thrown at them (16\%). While a third of Tanzanian women aged 1549 are estimated to have experienced physical violence from their husbands or partners, a considerable proportion of Tanzanian men (38\%) and women (54\%) find wife beating is justifiable (Jacobsen, 2014). Violent treatment against women is also supported by Betron (2008) and Vyas (2012) who reported that both men and women acknowledge women being beaten by men when they were not ready for sexual intercourse with their husbands or partners.

\section{Literature Review}

Studies have shown that exposure to parental violence puts children at risk for increased posttraumatic stress disorder (PTSD) symptoms, including diminished concentration, sleep disturbance, sudden startling and intrusive thoughts. These symptoms interfere with children's concentration by making it more difficult to pay attention to lessons taught in the classroom (Medina, Margolin \& Gordis, 2013; Margolin \& Gordis 2000; Schwartz \& Proctor, 2000) In addition, children's efforts to manage the emotional consequences of violence exposure interfere with school adaptation achievement. Research has shown that children use both unfavorable behavior and attention disengagement to cope with stress and reduce anxiety. Thus, children's efforts to cope with anxiety and PTSD may have deleterious effects on their attention and ability to solve problems (Schwartz \& Proctor, 2000). Therefore, school children's exposure to violence between parents is found to be critical, affecting their concentration during the teaching and learning processes.

Regarding children's inattentive behaviors in the classroom, Medina et al (2013) observed that children who have been traumatized and suffered from internalized behaviors are more likely to be totally withdrawn from their classes because their state of mind becomes disconnected from the classroom environment, which results to poor concentration. Osofsky, Wewers, Hann and Fick (1993) posited that children who have difficulty with attention may not be sensitive to important social instruction and expectations; thus, they find themselves struggling with school rules, peer relationships, and classroom instructions. The authors went on elaborating that deficits in attention undermine the child's ability to accomplish the central requirements of academic achievement and school adaptation.

Moreover, studies have related the children's gender with the effects of parental violence including externalized and internalized behaviors. Some studies have found that gender moderates the effects of exposure to violence. For instance, Evans, Davies and DiLillo (2008), Moylan, Herrenkohl, Sousa, Tajma, Herrenkohl and Russo ( 2011) reported that effect size of externalizing behavioral problems was significantly higher for boys exposed to violent homes than for girls. Other studies, however, found that girls exposed to violent homes were at higher risk for both 
internalizing and externalizing behaviors than boys (Heyman \& Slep, 2002; Sternberg, Baradaran, Abbot, Lamb \& Guterman, 2006; Holden \& Ritchie, 1991). Given the contrasting findings on gender differences in exposure effects, there is need for more well-designed studies on the issue (Herrenkohl et al., 2008; Widom. 1998). This study, however, focused on children's inattentive behaviors in the classroom due to witnessing parental violence specifically physical assault by husbands against mothers.

Violence against women is a problem in Tanzania (National Bureau of Statistics (2011). The National Bureau of Statistics (2011) reported that slapping was among the most common of the husband's acts of physical violence against their wives. The report further revealed that (36\%) of married women experienced slapping, followed by being punched (18\%), and being pushed, or had something thrown at them (16\%). A study by UNECA and ACGSD (2010)) reported that in Tanzania, spousal violence was highly prevalent and was accepted for a husband to treat his wife as he wished. The report also revealed that wife beating occurred at all levels of society. The study showed that $67 \%$ of respondents admitted that physical violence was often used to coerce women and make them submissive. It was found that many forms of gender-based violence, including domestic violence, were seen as normal. Williams, Larsen, and McCloskey's (2004) study on violence against women in Kilimanjaro found that nearly one in three women had been physically assaulted by her husband or partner. The study indicated that physical violence and partner abuse sometimes resulted into severe psychological and physical injuries on women.

TAMWA (2013) in Tanzania, conducted a five regions study on women beating including Nkansi district in Rukwa region, Babati district in Manyara region, Mtwara region, Kahama district in Shinyanga region and Musoma district in Mara region. In Nkansi district it was reported that wife beating was a normal practice in the villages. It was further reported that drunken husbands beat their wives anytime and anywhere even in public. In Babati district, the Police Gender Desk Officer revealed that there were so many incidents of wife beating going unreported due to traditional family beliefs. In Mtwara region, the report showed that cashew nut harvest season went hand in hand with wife beating especially when husbands married new wives using cash earned from sale of cashew nuts. The older wife/wives suffered beatings for demanding explanations on how the harvest money was spent. In Kahama district, the study indicated that there were many incidents of women beating due to excessive alcoholic use by husbands. The beatings happened when wives complained about the lack of basic needs at home and men's involvement in extra marital affairs. In Musoma district, it was indicated that women were sometimes beaten due to outdated customs and traditions whereby it was believed that women only respected husbands who beat them.

\section{The Study Gap}

The reviewed literature has further indicated that only studies from other countries have examined the effects of violence against women on children's school behaviors including concentration in school settings (Sanchez, Levison and Assaad 2013; Durand, Schraiber, Franka, and Barros, 2011; Geffner, Spurling \& Zelner, 2003; McGee, 2000). Most studies done in Tanzania have in general focused on physical, social and to some extent on psychological effects that face women in general (Vyas, 2012; MHSW, 2011; Gonzalez-brenes, 2003).Thus, available studies reviewed so far, specifically from Tanzania leave unanswered question. For instance, what are the children's school progress and behaviors from mothers exposed to violent husbands? This implies that knowledge and existing literature on the effect of parental violence on children's school behaviors is lacking.

The fact that children suffer from adverse effects in a household where violence between parents occurs is undisputed (Peterson, 1991; Thompson \& Trice-Black, 2012). Children exposed to domestic violence are more likely to miss school and suffer from poor health (Arias, 2004). It was, therefore, very important for this study to investigate on the effect of physical violence against mothers on children's school behaviors in primary schools. The study was guided by three research questions:

1. To what extent physical violence against wives by husbands result to children's poor concentration in the classroom?

2. To what extent physical violence against mothers affects children's attentiveness in the classroom by gender? 
3. Are there other factors which lead to children's poor concentration in the classroom?

\section{Research Methodology}

This section presents the methodology that guided the study.

\section{Research Design}

The data were quantitatively collected through the cross-sectional survey design to explain the extent to which physical violence on mothers by husbands related to school children's concentration in the classroom. The survey was carried out in Chamwino-Dodoma. The design aimed to present the data in quantitative form on how the pupils' pattern of negative school behaviors such as lack of concentration in the classroom is associated by physical violence against their mothers. The researcher was able to relate the pupils' concentration in the classroom (as dependent variable) with exposed and non-exposed mothers to physical violence (as independent variable). The design also enabled the researcher to get information on respondents from a population within a short period of time with less cost (Cohen, Manion, \& Morrison, 2011, p. 147). Thus, children's school behavioral data was collected within a short period of time. Furthermore, the cross-sectional survey provides generalizability within a given population and consolidates a degree of confidence which has an assurance in findings (Cohen et al, 2011).

\section{Population and Sampling}

Simple random sampling technique was employed to select a sample of 312 children from five primary schools with a population of 652 children from class four, five and six. The questionnaires were administered to the selected 312 primary school children. The sample size was obtained by using a table for determining the sample size for random samples as suggested by Cohen et al. (2011), and online sample size calculator (Survey Research System, 2012). With regard to the table by Cohen et al, (2011, p. 147), the population of 652 with confidence level of $95 \%$ has the following confidence intervals (degree of accuracy) with probability of sample size, $5 \%$ (241), $4 \%$ (312), and $3 \%$ (404). This survey chose the degree of accuracy of $4 \%$ that corresponds to a sample size of 312 .

A total of 110 children indicated their mothers to experience physical violence from husbands. While
202 showed their mothers were not exposed to physical violence. Hence, children's attentiveness in the classroom from mothers exposed to physical violence was related with children whose mothers were not. Finkelhor, Hamby, Omrod, \& Turner (2005); Edleson, Katy and Narae (2007). CEDV scale was adapted and modified to suit the Tanzanian context. Questionnaires of both close-ended and open-ended items were filled in by school children.

\section{Validity and Reliability}

The validity of the questionnaire was achieved through reviewing the related literature regarding the theoretical knowledge and concepts that were used in the study before preparing the instruments for the survey. The validity of data was achieved through preparing an appropriate and adequate questionnaire items for data collection. The reliability of the items employed in the questionnaire was then assessed by determining Cronbach's Alpha coefficients. The overall Cronbach's Alpha was 0.95, which enabled the researcher to continue using questionnaire in the real field of study.

\section{Data Analysis}

The questionnaires were entered into computer using the statistical package for social sciences (SPSS) version 20. Chi square test was used to examine the relationship between violence against mothers and children's attentiveness at 0.05 level of significance. The data were also analyzed by using SPSS to obtain descriptive statistics such as frequencies and percentages. The internal consistency among the items was assessed by determining Cronbach's Alpha coefficients of 0.7. The strength for relationship between the variables was measured by Phi and Cramer's V coefficient. Regarding strength for association between the variables, the small, medium and large limits were used. Thus, $r=.10$ to .29 or $r=-.10$ to -.29 (small strength), $r=.30$ to .49 or $r=-.30$ to -.49 (medium), $r=.50$ to 1.0 or $r=-.50$ to -.1 .0 (large).

\section{Results and Discussion}

The first research question asked about the extent to which physical violence against wives by husbands result to children's poor concentration in the classroom. The children's attentiveness in the classroom was examined in relation to their physically abused and non-abused mothers. Table 1 indicates that there was a statistically significant relationship between the children's attentiveness from mothers exposed to physical violence with 
those from non-mothers exposed to physical violence in the following items: "I fail to listen properly to teachers when they teach in the classroom because of the memories about my parents at home" $\left(X^{2}=12.064, p=.017\right)$ with small strength for association (Phi \& Crammer's V = .197) and "I fail to follow the school regulations because of the memories about my parents at home" $\left(X^{2}=13.512, \quad p=.009\right)$ with small strength for association (Phi \& Crammer's V = .208). It means that more children from mothers exposed to physical violence experienced lack of concentration on school regulations and when teachers taught in the classroom than children whose mothers were not exposed to violence. Table 1 indicates the association between children's attentiveness in the school setting and violence between parents.

Table 1: Children's Attentiveness Behaviors and Physical Violence on Mothers

\begin{tabular}{|c|c|c|c|c|c|c|c|c|}
\hline \multirow{3}{*}{ Items } & \multirow{3}{*}{$\begin{array}{l}\text { Likert } \\
\text { scales }\end{array}$} & \multicolumn{4}{|c|}{ Children's Situation } & \multirow{3}{*}{$\begin{array}{l}\text { Chi } \\
\text { squar } \\
\text { e }\end{array}$} & \multirow{3}{*}{$\begin{array}{l}\text { Sig. } \\
\text { (2taile } \\
\text { d) }\end{array}$} & \multirow{3}{*}{$\begin{array}{l}\text { Phi \& } \\
\text { Cramer } \\
\text { s V }\end{array}$} \\
\hline & & \multicolumn{2}{|c|}{$\begin{array}{l}\text { Children from } \\
\text { mothers } \\
\text { exposed to } \\
\text { physical } \\
\text { violence } \\
(\mathrm{N}=110)\end{array}$} & \multicolumn{2}{|c|}{$\begin{array}{l}\text { Children } \\
\text { from } \\
\text { mothers } \\
\text { not } \\
\text { exposed to } \\
\text { physical } \\
\text { violence } \\
(\mathrm{N}=202)\end{array}$} & & & \\
\hline & & $\mathrm{N}$ & $\%$ & $\mathrm{~N}$ & $\%$ & & & \\
\hline I fail to listen properly & Very often & 33 & 30 & 41 & 20.3 & & & \\
\hline to & Often & 24 & 21.8 & 27 & 13.4 & & & \\
\hline teachers when they & Rare & 11 & 10 & 16 & 7.9 & & & \\
\hline teach in the class & Very rare & 5 & 4.5 & 12 & 5.9 & & & \\
\hline $\begin{array}{l}\text { because of the } \\
\text { memories about my } \\
\text { parents, situation at } \\
\text { home }\end{array}$ & Never & 37 & 33.6 & 106 & 52.5 & $\begin{array}{c}12.06 \\
4\end{array}$ & .017 & .197 \\
\hline I fail to follow & Very often & 19 & 17.3 & 23 & 11.4 & & & \\
\hline instructions given by & Often & 20 & 18.2 & 27 & 13.4 & & & \\
\hline teachers on duty & Rare & 21 & 19.1 & 25 & 12.4 & & & \\
\hline because of the & Very rare & 14 & 12.7 & 19 & 9.4 & & & \\
\hline $\begin{array}{l}\text { memories about my } \\
\text { parents' situation at } \\
\text { home }\end{array}$ & Never & 36 & 32.7 & 108 & 53.5 & $\begin{array}{c}12.48 \\
6\end{array}$ & .014 & .200 \\
\hline I fail to follow the & Very often & 15 & 13.6 & 16 & 7.9 & & & \\
\hline school regulations & Often & 19 & 17.3 & 22 & 10.9 & & & \\
\hline because of the & Rare & 26 & 23.6 & 30 & 14.9 & & & \\
\hline memories about my & Very rare & 13 & 11.8 & 27 & 13.4 & & & \\
\hline $\begin{array}{l}\text { parents' situation } \\
\text { at home }\end{array}$ & Never & 37 & 33.6 & 107 & 57.4 & $\begin{array}{c}13.51 \\
2\end{array}$ & .009 & .208 \\
\hline
\end{tabular}

Table 1, reveals a statistically significant relationship between the children's attentiveness from mothers exposed to physical violence with those from nonmothers exposed to physical violence in the item "I fail to follow instructions given by the teacher on duty because of the memories about my parents at home" ( $\left.X^{2}=12.486, p=.014\right)$. The test for strength of relationship was small (Phi \& Crammer's V = .200).

Children's Attentiveness Behaviors by Gender The second question was about to what extent physical violence against mothers affects children's attentiveness in the classroom by gender?
Regarding children's attentive behaviors due to exposure to physical violence against their mothers, female children indicated being more inattentive during the teaching and learning processes than male children. For example, Figure 1 presents the results for the item "I fail to listen properly to teachers when they teach in the classroom because of the memories about my parent's situation at home." The results show that female children, 29 (48.8\%) very often failed to listen to teachers in the classroom when they recalled about the parents' situation at home than male children, 5 (9.6\%). Other Likert scales were 
rated by female and male children as follows: often, $16(27.6 \%)$ and $8(15.4 \%)$, rare $6(10.3 \%)$ and 5 (9.6\%).

Figure 1 further indicates the 'very rare' scale was rated, 1 (1.7) and 4 (7.7\%) by female and male children respectively. "Never" was rated 7 (12.1\%) and $30(57.7 \%)$ by female and male children respectively. Moreover, there was a statistically significant relationship for the item "I fail to listen properly to teachers when they teach in the classroom because of the memories about my parent's situation at home" $\left(X^{2}=34.661, p=.000\right)$. The test for strength of relationship was large (Phi \& Crammer's $V=.561$ ).

Figure 1: Children's Attentiveness Behaviors within the School Setting by Gender

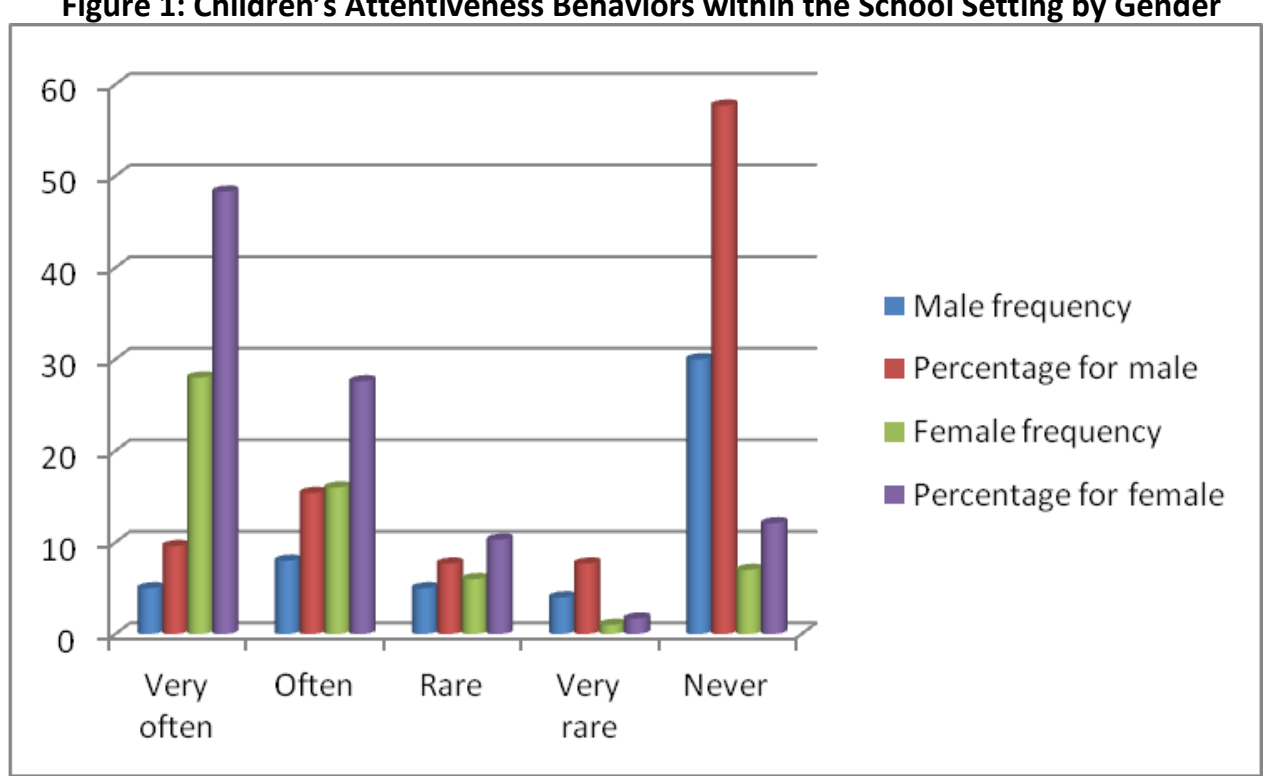

Table 2: Other Reasons that made Children pay less Attention in the Classroom

\begin{tabular}{lccccc}
\hline \multicolumn{1}{c}{ Reasons } & \multicolumn{2}{c}{ Yes } & \multicolumn{2}{c}{ No } \\
& $\mathbf{N}$ & $\%$ & $\mathbf{N}$ & $\%$ \\
\hline Tiredness & 13 & 11.8 & 97 & 88.2 \\
Hungry & 9 & 8.2 & 101 & 91.8 \\
Thinking about inadequacy Of school needs & 8 & 7.3 & 102 & 92.7 \\
such as pens etc. & & & & \\
\hline
\end{tabular}

The third question stated: are there other factors which lead to children's poor concentration in the classroom? Twenty five (22.7\%) out of 110 children from physically abused mothers admitted that there were other reasons that made them fail to concentrate in the school environment. Eighty five (77.3\%) out of 110 children responded that there were no other reasons that made them inattentive in the school setting. Table 2 summarizes the reasons that made children pay less attention within the school setting.

The results in the Table 2 shows that 13 (11.8\%) out of 110 children from physically abused mothers paid less attention within the setting because of tiredness. Eight (7.3\%) out of 110 children from physically abused mothers also were not attentive in the school setting as they were thinking about inadequacy of school needs such as pens, exercise books and other things. The results show that despite the children's poor concentration in the classroom due to the reflection of parental violence at home, children also experienced inattentiveness in the classroom because of tiredness and lack of learning materials like pens and other learning materials.

\section{Discussion}

The results revealed a strong link between the children's inadequate concentration in the school setting particularly in the classroom and physical violence against their mothers. These findings further bring light to the complex interplay of school going children's problems such as attentiveness variables on spousal maltreatments. The results concur with Bowlby's (1969, 1973) theory of attachment which depicts this situation by revealing that frustrated mothers can be 
inconsistent and unresponsive in providing basic services and supervision to children, thus, resulting to poor concentration of children in the classroom. Employing hypothesis and theory to analyze whether or not violence against women including mothers has adverse effects on children's concentration in the classroom provides insight on how these variables relate. The results further assist in identifying the factors that are associated with domestic violence in Tanzania in a wide context of individual, family and community in general.

The findings indicate that some children experienced difficulties of concentration while learning in the classroom due to the flow of repetition of bad memories on parental violence at home. Moreover, hunger and thinking about lack of basic school needs such as exercise books and pens slightly contributed to poor concentration in the classroom. It is further clear that mothers, for instance, in rural areas in Tanzania are over burdened with multiple tasks such as tilling the land, taking care of children, fetching water and cooking. Children's concentration in the classroom is thus endangered by mothers' poor provision of basic needs to them resulting from intimate partner violence. Bowlby's theory $(1969,1973)$ insists about the inadequate secure attachment and basic needs from mothers can lead to a negative impact on children's behavior. The findings are in line with previous studies by Medina, Margolin and Gordis (2013), who emphasize that anxiety and depression, interfere with children's concentration by making it more difficult to pay attention to lessons taught in the classroom. These results are further supported by Medina et al (2013), who observed that children who have been traumatized and suffered from internalized behaviors are more likely to be totally withdrawn from their class because their state of mind becomes disconnected from the classroom environment

\section{Conclusions and Recommendations \\ Conclusion}

The findings have shown that there is a relationship between inter parental conflicts and pupils' poor concentration in the learning environment specifically in the classroom. The results have indicated that parental violence affect both male and female attention in the classroom regarding physical violence against their mothers though female pupils were more affected than male pupils. Mothers' failure in providing children's services because of husbands' violence make children suffer from hunger, despair, fear and worry, hence, pay little attention to teachers while teaching.

\section{Recommendations}

The researcher recommends that it is important to develop training through psycho-education within families, community, and governmental and nongovernmental institutions in order to intervene or prevent intimate partner violence. The Ministry of Education and Vocational Training should also establish the effective guidance and counselling services in primary schools with trained counsellors to support pupils with various problems including those who have problems of concentration in the school setting. Furthermore, in a context where the policies and laws on domestic violence are in the initial stage for implementation, it is important to investigate and examine the factors that precipitate violence against women in general. With reference to these results, any effective intervention strategy should have both legal and institutional dimensional in order to protect maltreatments against mothers and target disadvantaged groups such as children including school going pupils.

\section{References}

Abayomi, A.A. (2013). Sociological implications of domestic violence on children's development in Nigeria. Journal of Africa Studies and Development, 6 (1), 8-13.

Arias, I. (2004). Report from the CDC. The legacy of child maltreatment: Long-term health consequences for women. Journal of Women's Health, 13 (5), 468-473.

Baumgartner, J. N., Kaaya, S., Karungula, H., Kaale, A., Headley, J., \& Tolley, E. (2015). Domestic violence among adolescents in HIV prevention research in Tanzania: Participant experiences and measurement issues. Maternal Child Health Journal, 19, 33-39.

Betron, M. (2008). Gender-based violence in Tanzania: An assessment of policies, services and promising interventions. Retrieved April 30, 2015, from http://www.mcdgc.go.tz/data/PNADN.pdf.

Bowlby, J. (1969). Attachment and loss: Attachment. New York: Basic Books Inc. 
Bowlby, J. (1973). Attachment and loss: Separation, anxiety and anger. New York: Basic Books.

Cohen, L., Manion, L., \& Morrison, K. (2011). Research methods in education $\left(7^{\text {th }} \mathrm{Ed}\right)$. London: Routledge.

Durand, J.B., Schraiber, L.B., Franca, I., \& Barrows, C. (2011). Impact of exposure to intimate partner violence on children's behaviour. Revista de Saude Publica, 45 (3), 355-364.

Edleson, J.L. (1999). Children's witnessing of adult domestic violence. Journal of Interpersonal Violence, 14 (8), 839-870.

Edleson, J.L., Katy, K. J., \& Narae, S. (2007). Children's exposure to domestic violence Scale user manual. Minnesota: University of Minnesota.

Emery, C. R. (2013). Controlling for selection effects in relationship between child behaviour problems and exposure to intimate partner violence. Journal of Interpersonal Violence, 26 (8), 1541-1558.

Evans, S. E., Davies, C., \& DiLillo, D. (2008). Exposure to domestic violence: A meta-analysis of child and adolescent outcomes. Aggression and Violent Behaviours, 13, 131-140.

Finkelhor, D., Hamby, S.L., Omrod, R., \& Turner, H. (2005). The juvenile victimization questionnaire: Reliability, validity and national norms. Child Abuse and Neglect, 29, 383-412.

Herrenkohl, T. I., Sousa, C., Tajima, E.A., Herrenkohl, R. C. \& Moylan, C. A. (2008). Intersection of child abuse and children's exposure to domestic violence. Trauma, Violence \& Abuse, 2, 88-99.

Geffner, R., Spurling, R.S., \& Zelner, J. (2003. The effects of intimate partner violence on children. London: The Haworth Maltreament and Trauma Pres.

Gluck, S. (2012). Effects of domestic violence on women and children. Retrieved September 15, 2014, from www.health.com /abuse/violence/effects-of-domestic-violenc e-domesti-abuse-on-women-and-children.

Gonzalez-Brenes, M (2003). Domestic violence, bargaining and fertility in rural Tanzania,
Research Paper, University of CaliforniaBerkeley.

Heyman, R. E., \& Slep, A. M. (2002). Do child abuse and interparental violence lead to adulthood family violence? Journal of Marriage and Family, 64, 864-870.

Holden, G. W., \& Ritchie, K. L. (1991). Linking extreme marital discord, child rearing and child behaviour problems: Evidence from battered women. Child Development, 62, 311-327.

Jaluo, M.N. (2011). An investigation into the causes of domestic violence and their effects on learning in childhood in Lugari Kenya. Unpublished M.A Thesis, University of Moi.

Jayasinghe, S., Jayawardena, P., \& Perera, H. (2009). Influence of intimate partner violence on behaviour, psychological status and school performance in Sri Lanka. Journal of Family Studies, 15: 274-283.

Magwa, S. (2013). Experiencing and witnessing domestic violence on school aged children. International Journal of Sociology, Science \& Education,3 (3), 587-591.

Margolin,G., \& Gordis, E.B. (2000). The effects of family and community violence on children. Annual review of psychology, 51,445-479.

McGee, C. (2000). Childhood experience of domestic violence. London: Jessica Kingsley Publishers.

Medina, A. M., Margolin, G., \& Gordis, E. B. (2013). Children's exposure to violence: Community violence, domestic violence and general effects. New York: Net Industries and Licensors.

MHSW. (2011). National management guidelines for the health sector: Response to and prevention of gender-based violence. The United Republic of Tanzania.

Moylan, C.A., Herrenkohl, T.I., Sousa, C., Tajima, E. A., Herrenkohl, R.C., \& Russo, M.J. (2011). The effects of child abuse and exposed to domestic violence on adolescent internalizing and externalizing behavioural problems, Journal of Family Violence, 25 (1), 53-63. 
National Bureau of Statistics. (2011). Tanzania demographic and health survey 2010. The United Republic of Tanzania. Government Publishers.

Osofsky, J.D., Wewers, S., Hann, D.M., \& Fick, A.N. (1993). Chronic community violence: What is happening to our children?. In D. Reiss., J . E. Richters., M. Radke-Yarrow \& D. Scharff (ed), Children and violence. New York: Guilford.

Thompson, E.H., \& Trice-Black, S. (2012). Schoolbased group interventions for children exposed to domestic violence. Journal of Family Violence, 27, 233-241.

Richards, K. (2011). Children's exposure to domestic violence in Australia. Canberra: Institute of Criminology Press.

Peterson, D. (1991). Physically violent husbands of the 1980s and their resources. Journal of Family Violence, 6 (1), 1-15.

Sanchez, G.F., Levison, D., \& Assaad. R. (2013). Methodological challenges in studying the impact of domestic violence on children's human capital: An application to Columbia. Minnesota: University of Minnesota.

Schwartz, D., \& Proctor, L. (2000). Community violence exposure and children's social adjustment in school peer group: The mediating roles of emotion regulation and social cognition. Journal of Consulting and Clinical psychology, 68, 670-682.

Spilsbury, J. (2008). Profiles of behavioural problems in children who witness domestic violence. Violence and Victims, 23, (10, 317.
Sternberg, K. J., Baradaran, L. P., Abbot, C. B., Lamb, M. E., \& Guterman, E. (2006). Type of violence, age and gender differences in the effects of family violence on children's behaviour problems. A mega-analysis. Developmental Review, 26, 89-112.

Survey Research System, (2012). Creative research system: Sample size. Retrieved April 02, 2015, from www.surveysystems .com/s scale.htm.

TAMWA. (2013). Gender based violence: Research Report. Retrieved March 18, 2014, from www.inspired.org/content/upload/docume nt/tanzania.pdf

UNECA \& ACGSD. (2010). Violence against women in Africa: A situational analysis. Retrieved April 4, 2016, from www1.uneca.org./Portals/ Publications/21VAW in Africa-A situationalanalysis.

UNICEF. (2006). World report on violence against children. New York: UNICEF.

Vyas, S. (2012). Assessing the implications of women's economic status on intimate partner violence in Dar es Salaam and Mbeya, Tanzania. Published PhD Thesis, London School of Hygiene and Tropical Medicine.

Williams,C.M., Larsen, U.M., \& McCloskey, L.A.(2004). Violence against women. Boston: Harvard University.

Zerk, D.M., Mertin, P.G., \& Proeve, M. (2009). Domestic violence and maternal reports of young children's functioning. Journal of Family Violence, 24 (7), 423-432. 